Research Paper

\title{
Sequencing batch airlift reactors (SBAR): a suitable technology for treatment and valorization of mineral oil wastewaters towards lipids production
}

\author{
Rita M. Silva a, Ana M. Fernandes a, Francesca Fiume ${ }^{\mathrm{a}, 1}$, Ana Rita Castro ${ }^{\mathrm{a}}$, Raul Machado ${ }^{\mathrm{b}, \mathrm{c}}$, \\ Maria Alcina Pereira ${ }^{a, *}$ \\ ${ }^{a}$ Centre of Biological Engineering, University of Minho, Campus de Gualtar, 4710-057 Braga, Portugal \\ ${ }^{\mathrm{b}}$ CBMA Centre of Molecular and Environmental Biology, Department of Biology, University of Minho, Campus de Gualtar, 4710-057 Braga, Portugal \\ ${ }^{\mathrm{c}}$ IB-S Institute of Science and Innovation for Sustainability, University of Minho, Campus de Gualtar, 4710-057 Braga, Portugal
}

\section{A R T I C L E I N F O}

\section{Editor: Dr. J. He}

\section{Keywords:}

Hydrocarbon

Salinity

Biological treatment

Rhodococcus opacus

Alcanivorax borkumensis

Neutral lipids

\begin{abstract}
A B S T R A C T
Produced water (PW) and spent oil-based wastewaters are some of the largest mineral oil wastewaters produced. Due to the high toxicity of hydrocarbons, several countries set stringent discharge limits and its treatment is compulsory before discharge. In this work, biological treatment of mineral oil wastewaters coupled with the production of bacterial lipids is demonstrated in sequential batch airlift reactors (SBAR). Two SBAR (2 L working volume) were used for treatment of PW and lubricant-based wastewater (LW), inoculated with Alcanivorax borkumensis $\mathrm{SK} 2\left(\mathrm{SBAR}_{\mathrm{Ab}+\mathrm{PW}}\right)$ and Rhodococcus opacus $\mathrm{B} 4\left(\mathrm{SBAR}_{\mathrm{R} . \mathrm{o}+\mathrm{LW}}\right)$, respectively. A total petroleum hydrocarbon removal (TPH) efficiency up to $96 \%$ and $80 \%$ were achieved for $\mathrm{SBAR}_{\mathrm{Ab}+\mathrm{PW}}$ and $\mathrm{SBAR}$.o+LW, respectively. Intracellular lipids production in $\mathrm{SBAR}_{\mathrm{Ab}+\mathrm{PW}}$ increased when lower $\mathrm{TPH} / \mathrm{N}$ ratios and higher feast stage duration were applied (up to $0.74 \mathrm{~g} \mathrm{~g}^{-1}$ cell dry weight (CDW)), whereas in $\mathrm{SBAR}_{\mathrm{R} . \mathrm{o}+\mathrm{LW}}$ higher lipids production was observed for higher TPH/N ratios $\left(0.94 \mathrm{~g} \mathrm{~g}^{-1}\right.$ in CDW). Triacylglycerols (TAG) were the main intracellular lipid accumulated in both $\mathrm{SBAR}_{\mathrm{Ab}+\mathrm{PW}}$ and $\mathrm{SBAR}_{\mathrm{R} . \mathrm{o}+\mathrm{LW}}$ operations, while wax ester (WE) production was only observed extracellularly in the $\mathrm{SBAR}_{\mathrm{Ab}+\mathrm{PW}}$.
\end{abstract}

\section{Introduction}

The increasing demand for petroleum and petroleum derived products had led to the production of large amounts of mineral oil wastewaters, being spent oil-based wastewaters (SOW) and oilfield produced water $(\mathrm{PW})$ the most significantly produced. Lubricant-based wastewater (LW) is a common type of SOW that is produced during the manufacture and the application of lubricants in industrial activities (Castro et al., 2018). On the other hand, oilfield PW is the largest by-product generated during the process of oil and gas extraction with a worldwide production up to 39.5 billion litters per day (Jiménez et al., 2018). Industrial petrochemical wastewater treatment is an important study area in environmental engineering. Mineral oil wastewaters are very recalcitrant streams and due to the presence of large concentrations of petroleum hydrocarbons are considered an environmental problem with serious consequences to the environment and human health (Camarillo and Stringfellow, 2018). Therefore, the treatment of these wastewaters is compulsory and limits and rules regarding the organic content had been set for its discharge into the environment (Fakhru'l-Razi et al., 2009).

Nowadays, mineral oil wastewaters are commonly treated by different physical and/or chemical processes such as coagulation, adsorption, hydrocyclones, centrifugation and membrane processes (Aljuboury et al., 2017). However, these methods require high capital for installation and maintenance, high energy consumption and lead to the production of hazardous sludge (Dong et al., 2011).

Biological treatment of mineral oil-wastewaters offers some

\footnotetext{
* Corresponding author.

E-mail addresses: rita.silva@ceb.uminho.pt (R.M. Silva), anamargarida.bf@gmail.com (A.M. Fernandes), fra.fiume@gmail.com (F. Fiume), ritacastro@deb, uminho.pt (A.R. Castro), raulmachado@bio.uminho.pt (R. Machado), alcina@deb.uminho.pt (M.A. Pereira).

1 Present address: Research Centre for Animal Production and Aquaculture, Consiglio per la ricerca in agricoltura e l'analisi dell'economia agraria (CREA), Via

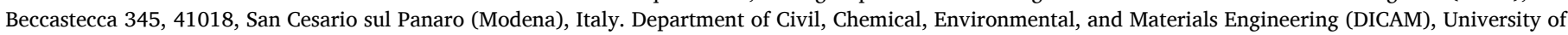

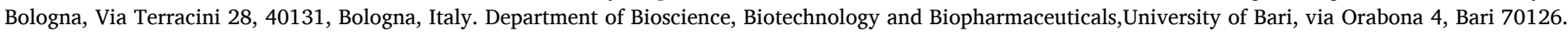




\begin{tabular}{|c|c|}
\hline \multicolumn{2}{|c|}{ Nomenclature } \\
\hline ATR-FTIR & $\begin{array}{l}\text { Attenuated total reflection-fourier transform infrared } \\
\text { analysis }\end{array}$ \\
\hline CDW & Cellular dry weight \\
\hline COD & Chemical oxygen demand \\
\hline DAG & Diacylglycerol \\
\hline FA & Fatty acid \\
\hline GC-FID & Gas chromatography and Flame ionization detector \\
\hline HCB & Hydrocarbonoclastic bacteria \\
\hline LW & Lubricant wastewater \\
\hline MAG & Monoacylglycerols \\
\hline PAH & Polycyclic aromatic hydrocarbons \\
\hline PW & Produced water \\
\hline
\end{tabular}

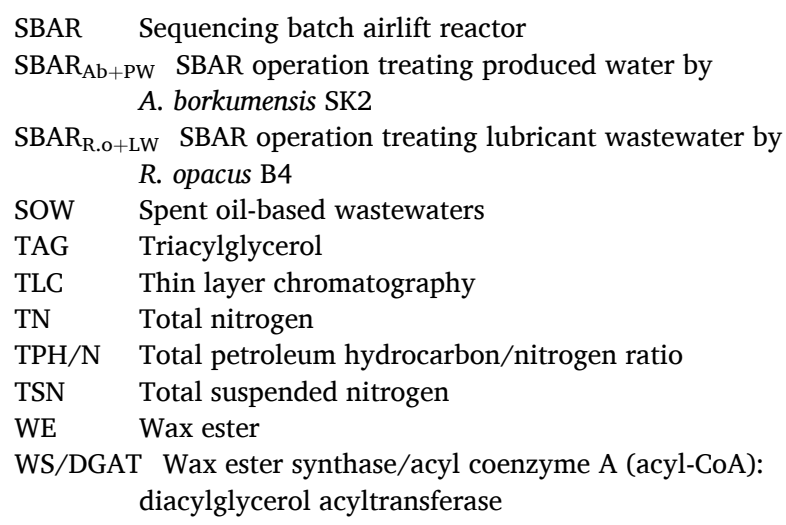

advantages to the current physical and chemical processes. It is a more cost-effective method, allowing to remove the small suspended oil particles that cannot be eliminated otherwise and environmental friendly, since it relies in bacteria capability to transform hydrocarbons into nontoxic by-products such as carbon dioxide $\left(\mathrm{CO}_{2}\right)$, water or bacterial reserve compounds (Dong et al., 2011; Fakhru'l-Razi et al., 2009).

Several works have been focused on the aerobic treatment of hydrocarbon contaminated wastewaters since it occurs at a faster rate and is more efficient than under anaerobic conditions (Da Silva et al., 2016; Heider et al., 1998; Sudmalis et al., 2018). Mineral oil wastewaters, like for instance PW and LW, differ from each other relatively to the type and content of hydrocarbons, salinity levels and presence of some other specific compounds. For example, PW consists mainly on aliphatic hydrocarbons from $\mathrm{C} 11$ to $\mathrm{C} 40$, which are more easily biodegradable than aromatic hydrocarbons (Sudmalis et al., 2018), while LW is composed by a complex matrix that includes a mixture of straight-chain alkanes ranging from C10 to C34 and a complex and unresolved hydrocarbon mixture (Da Silva et al., 2016). Another important feature of mineral oil wastewaters is the salinity levels which in the case of offshore PW can be challenging when a biological treatment is applied. Therefore, the use of hydrocarbonoclastic bacteria (HCB) and in the particular case of offshore PW, halotolerant HCB, can be a suitable strategy for aerobic treatment of mineral oil wastewaters such as PW and LW (Da Silva et al., 2016; Sudmalis et al., 2018).

One particular feature of HCB is the accumulation of storage compounds in response to nutrient limitation in the environment. Alcanivorax borkumensis SK2 and Rhodococcus opacus B4 are two HCB species capable of degrading a wide range of hydrocarbons and use them as carbon source for the production and accumulation of neutral lipids (Alvarez and Steinbüchel, 2002; Manilla-Pérez et al., 2011). The accumulation of lipids occurs as a survival strategy during starvation periods, when an essential nutrient (i.e nitrogen and/or phosphorous) becomes unavailable or at lower concentrations comparing with the carbon source (Kalscheuer et al., 2007; Manilla-Pérez et al., 2011). Several factors can influence the production of storage compounds by bacteria. Some studies reported that the carbon to nitrogen ratio (COD/N ratio) is the most important parameter influencing the production and accumulation of lipophilic compounds by HCB (Manilla-Pérez et al., 2011; Zhang et al., 2019). Currently, bacterial neutral lipids are of great interest as raw materials for production of biofuels or other oleochemical products (Castro et al., 2017; Kumar et al., 2015).

Previous studies performed by our research group reported A. borkumensis SK2 ability to produce intracellular and extracellular lipids, namely WE and TAG, as well as R. opacus PD630 and B4 ability to produce intracellular TAG, from mineral oil wastewaters (Castro et al., 2016; Da Silva et al., 2016; Sudmalis et al., 2018). Due to these remarkable characteristics, A. borkumensis SK2 (halophilic) and $R$. opacus B4, were chosen for the treatment of PW and LW respectively.
Moreover, A. borkumensis SK2 was chosen due to its wide presence in marine environments.

Combining aerobic biological treatment with the valorization of mineral oil-based wastewaters can be an environmentally sustainable alternative for the management of these wastewaters. After showing that A. borkumensis SK2 and $R$. opacus B4 are suitable candidates for the treatment process, it is important to study the most appropriate process conditions and bioreactor configurations for the optimization and application of a full-scale treatment.

In this work the suitability of the sequencing batch airlift reactor (SBAR) configuration to biologically treat different types of mineral oil wastewaters namely PW (saline wastewater) and LW (non-saline wastewater) was explored. A specialized inoculum focused in PW and LW characteristics, namely salinity level, was used and the most suitable conditions for the production and accumulation of bacterial lipids were assessed, in order to achieve a balance between neutral lipids production and wastewater treatment costs and efficiency.

\section{Materials and methods}

\subsection{Experimental set-up, inoculum and carbon source}

A SBAR with a working volume of $2 \mathrm{~L}$, designated as $\mathrm{SBAR}_{\mathrm{Ab}+\mathrm{PW}}$, was inoculated with $A$. borkumensis SK2 (DSM 11573), fed with oilfield produced water $(\mathrm{PW})$ and operated at room temperature $\left(20 \pm 5^{\circ} \mathrm{C}\right)$ and $\mathrm{pH}$ around 7.8. Another SBAR with the same working volume, desig-

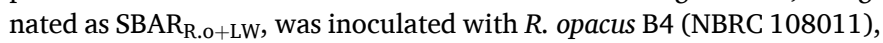
fed with lubricant-based wastewater (LW) at different concentrations and operated at room temperature $\left(20 \pm 5{ }^{\circ} \mathrm{C}\right)$ and $\mathrm{pH}$ around 7.3.

PW concentrate was obtained from Shell (The Netherlands), from a full-scale physical separation process. LW concentrate (floating phase separated in a gravimetric oil/water separation unit) was obtained from a wastewater treatment plant located in a heavy machinery maintenance service unit (ALSTOM Portugal, S.A., Maia, Portugal). The chemical

Table 1

Chemical characterization of the concentrates of lubricant-based wastewater (LW) and oilfield produced water (PW).

\begin{tabular}{|c|c|c|}
\hline Characterization & LW & PW \\
\hline $\operatorname{COD}\left(\mathrm{g} \mathrm{L}^{-1}\right)$ & $317 \pm 14$ & n.d $\mathrm{d}^{\mathrm{a}}$ \\
\hline Nitrate $\left(\mathrm{mg} \mathrm{L}^{-1}\right)$ & $94 \pm 9$ & n.d $\mathrm{d}^{\mathrm{a}}$ \\
\hline Nitrite $\left(\mathrm{mg} \mathrm{L}^{-1}\right)$ & 0 & n.d $\mathrm{d}^{\mathrm{a}}$ \\
\hline Total ammonia nitrogen $\left(\mathrm{mg} \mathrm{L}^{-1}\right)$ & $0.13 \pm 0.4$ & $1.2 \pm 0.08$ \\
\hline Total nitrogen $\left(\mathrm{mg} \mathrm{L}^{-1}\right)$ & $172 \pm 0.4$ & $43 \pm 2.7$ \\
\hline Salinity ( $\mathrm{g} \mathrm{kg}^{-1}$ of seawater) & 0 & 200 \\
\hline Total petroleum hydrocarbons (TPH) $\left(\mathrm{g} \mathrm{L}^{-1}\right)$ & $177 \pm 17$ & $202 \pm 16$ \\
\hline
\end{tabular}

${ }^{a}$ Value not determined due to interferences of the high chloride levels in the quantification method. 
characterization of LW and PW is described in Table 1.

A. borkumensis SK2 was pre-grown in saline medium (ONR7a) according to DMSZ, Braunschweig, Germany and R. opacus B4 in Mineral Salts (MS) medium according to Schlegel et al. (1961) (please see Supplementary information for details and Fig. S1).

A short adaptation period of the microorganisms to the respective carbon source was performed before SBAR operations. In this period both carbon (PW or LW) and nitrogen source (ammonium chloride $\left(\mathrm{NH}_{4} \mathrm{Cl}\right)$ ) were added to the bioreactors at the conditions of $0.26 \mathrm{~g} \mathrm{~L}^{-1}$ of $\mathrm{TPH}$ and $30 \mathrm{mg} \mathrm{L}^{-1}$ of nitrogen for SBAR $\mathrm{Ab}+\mathrm{PW}$ and $1 \mathrm{~g} \mathrm{~L}^{-1}$ of TPH and $30 \mathrm{mg} \mathrm{L}{ }^{-1}$ of nitrogen for $\mathrm{SBAR}_{\mathrm{R} . \mathrm{o}+\mathrm{LW}}$. The wastewaters treatment process consisted in alternated cycles of feast (carbon addition) and famine (nitrogen addition) stages. In the famine stage, only nitrogen (at concentrations of 15 or $30 \mathrm{mg} \mathrm{L}^{-1}$ ) was added to the bioreactor. This stage was necessary to ensure that all the carbon from the previous cycle was totally consumed before the carbon source addition. In the feast stage, only the carbon source was added (Fig. S2, Supplementary material).

Different ratios of total petroleum hydrocarbons per nitrogen concentration (TPH/N ratios) and feast stage duration were tested for both wastewaters. The operational conditions are described in Table 2 for $\mathrm{SBAR}_{\mathrm{Ab}+\mathrm{PW}}$ and Table 3 for SBAR R.o+LW. In both SBAR operations and for each condition tested, three cycles were performed with exception of the condition of $4.4 \mathrm{~g} \mathrm{~L}^{-1}$ of $\mathrm{TPH}_{\mathrm{LW}}$ and $15 \mathrm{mg} \mathrm{L}^{-1}$ of nitrogen in $\mathrm{SBAR}_{\mathrm{R}}$. $\mathrm{o}+\mathrm{LW}$, where only two cycles were made. At the end of each cycle, analysis on neutral lipids, total nitrogen and total petroleum hydrocarbons concentration were performed.

\subsection{Analytical procedures}

Bacterial growth in the seed cultures used for bioreactors inoculation was monitored by optical density at $600 \mathrm{~nm}$ wavelength $\left(\mathrm{OD}_{600}\right)$ in a $\mathrm{DR}$ 2800 Hach Lange spectrophotometer.

During reactors operation, $2 \mathrm{~mL}$ samples were collected daily and centrifuged at $10,000 \mathrm{rpm}$ for $10 \mathrm{~min}$ for nitrogen determination $(\mathrm{N}$ $\mathrm{NH}_{4}^{+}$), using the commercial kit LCK 304 (Hach Lange ${ }^{\circledR}$, Germany). At the end of each cycle total nitrogen (TN) determination was performed, using the commercial kits LCK 338 (Hach Lange ${ }^{\circledR}$, Germany). Biomass concentration was measured as total suspended nitrogen (TSN), using the commercial kit LCK 304 (Hach Lange $®$, Germany).

Chemical oxygen demand (COD), nitrite and nitrate concentrations were determined using the commercial kit LCK 914, LCK 342 and LCK 339 , respectively (Hach Lange ${ }^{\circledR}$, Germany).

The $\mathrm{pH}$ was manually controlled and measured by using a benchtop metre inoLabVR pH 7110 (WTW, Weilheim, Germany). The adjustment was performed by adding hydrochloric acid $(\mathrm{HCl})$ with a syringe to the bioreactor until reaching the optimal $\mathrm{pH}$.

\subsection{Extraction and quantification of total petroleum hydrocarbons $(\mathrm{TPH})$}

Samples of $50 \mathrm{~mL}$ (in duplicate) were collected for hydrocarbons

Table 2

Operational conditions applied to the SBAR inoculated with A. borkumensis SK2 for the biological treatment of $\mathrm{PW}\left(\mathrm{SBAR}_{\mathrm{Ab}+\mathrm{PW}}\right)$.

\begin{tabular}{|c|c|c|c|c|c|}
\hline Cycles & $\begin{array}{l}\mathbf{T P H}_{\mathbf{P W}}{ }^{\mathrm{a}} \\
\left(\mathrm{g} \mathrm{L}^{-1}\right)\end{array}$ & $\begin{array}{l}\mathbf{N}-\mathrm{NH}_{4}{ }^{\mathrm{b}} \\
\left(\mathrm{mg} \mathrm{L}^{-1}\right)\end{array}$ & $\begin{array}{l}\text { DO } \\
(\mathrm{mg} \\
\left.\mathrm{L}^{-1}\right)\end{array}$ & $\begin{array}{l}\text { Feast stage } \\
\text { duration (d) }\end{array}$ & $\begin{array}{l}\text { Famine stage } \\
\text { duration (d) }\end{array}$ \\
\hline I-III & 0.26 & 30 & $7-8$ & 3 & 3 \\
\hline IV-V & 0.26 & 15 & $7-8$ & 2 & 2 \\
\hline VI-VIII & 0.26 & 15 & $7-8$ & 4 & 3 \\
\hline IX-XI & 0.26 & 30 & $7-8$ & 5 & 3 \\
\hline
\end{tabular}

a TPH concentration added to the bioreactor at the beginning of the feast stage.

$\mathrm{b}$ Nitrogen concentration added at the beginning of the famine stage.
Table 3

Operational conditions applied to the SBAR inoculated with $R$. opacus $\mathrm{B} 4$ for the biological treatment of $\mathrm{LW}\left(\mathrm{SBAR}_{\mathrm{R} . \mathrm{o}+\mathrm{LW}}\right)$.

\begin{tabular}{llllll}
\hline Cycles & $\begin{array}{l}\mathrm{TPH}_{\mathrm{LW}}{ }^{\mathrm{a}} \\
\left(\mathrm{g} \mathrm{L}^{-1}\right)\end{array}$ & $\begin{array}{l}\mathbf{N}^{-\mathrm{NH}_{4}} \\
\left(\mathrm{mg} \mathrm{L}^{-1}\right)\end{array}$ & $\begin{array}{l}\text { DO } \\
(\mathrm{mg} \\
\left.\mathrm{L}^{-1}\right)\end{array}$ & $\begin{array}{l}\text { Feast stage } \\
\text { duration (d) }\end{array}$ & $\begin{array}{l}\text { Famine stage } \\
\text { duration (d) }\end{array}$ \\
\hline I-III & 1 & 30 & $7-8$ & 5 & 2 \\
IV-VI & 4.4 & 30 & $7-8$ & 3 & 6 \\
VII-VIII & 4.4 & 15 & $7-8$ & 2 & 4 \\
\hline
\end{tabular}

${ }^{\text {a }}$ TPH concentration added to the bioreactor at the beginning of the feast stage.

$\mathrm{b}$ Nitrogen concentration added at the beginning of the famine stage.

analysis. The samples were acidified with $\mathrm{HCl}$ to a pH below 2 and preserved at temperatures below $5{ }^{\circ} \mathrm{C}$ until further analysis.

Hydrocarbons extraction was performed according to the international standard method ISO 9377-2 at room temperature as described in Castro et al. (2016), with the following modifications: the extraction was performed three times with $25 \mathrm{~mL}$ of hexane; and after the cleaning step, the samples were dried under a gentle flow of nitrogen in a TurboVap ${ }^{\circledR L V}$ (Biolage) at $51{ }^{\circ} \mathrm{C}$ for $40 \mathrm{~min}$ and resuspended in $1 \mathrm{~mL}$ of n-hexane for further analysis by gas chromatography with a flame ionization detector (GC-FID). The extracts were injected in a GC Varian ${ }^{\circledR}$ star 3400CX, USA equipped with a VF-1 ms column (30 m long, $0.25 \mathrm{~mm}$ diameter and $0.25 \mu \mathrm{m}$ film thickness). A sample volume of $2 \mu \mathrm{L}$ was injected at $250{ }^{\circ} \mathrm{C}$ with a split ratio of $1: 20$ and helium was used as carrier gas at a flow rate of $1 \mathrm{~mL} \mathrm{~min}{ }^{-1}$. The column temperature was set at $60{ }^{\circ} \mathrm{C}$ for $1 \mathrm{~min}$ and then increased until $270{ }^{\circ} \mathrm{C}$ at a rate of $8{ }^{\circ} \mathrm{C} \mathrm{min}{ }^{-1}$ in a total time run of $62 \mathrm{~min}$. The detector was operated at a temperature of $315^{\circ} \mathrm{C}$.

\subsection{Extraction and analysis of neutral lipids}

$30 \mathrm{~mL}$ samples were collected from the bioreactor for extraction and analysis of neutral lipids. The samples were centrifuged at 10,000 rpm for $10 \mathrm{~min}$ in a centrifuge Beckman allegra 64R. The pellet was freeze dried and used for intracellular lipids analysis. Intracellular lipids extraction was performed with chloroform: methanol $(2: 1, \mathrm{v} / \mathrm{v})$ as described in Castro et al. (2016).

For extracellular lipid extraction, the supernatant was mixed with chloroform: methanol $(2: 1, \mathrm{v} / \mathrm{v})$ in a separation funnel $(1: 1 \mathrm{vol} / \mathrm{v})$ for 2 $\mathrm{min}$ and left for $30 \mathrm{~min}$ to allow the separation between the aqueous and organic phases.

The organic phases were dried under a gentle flow of nitrogen in a TurboVap ${ }^{\circledR L V}$ (Biolage) at $51{ }^{\circ} \mathrm{C}$ for $40 \mathrm{~min}$ and resuspended in $500 \mu \mathrm{L}$ of chloroform.

Extracellular lipid extracts were fractionated by polarity on SPE columns ( $\mathrm{SiOH} 1 \mathrm{~g} / 6 \mathrm{cc}$ ) from Supelco, as described in Revellame et al. (2012).

The total lipid content was quantified gravimetrically. The different classes of lipids present in the extracts was assessed by TLC (Supplementary material).

\subsection{DNA extraction and sequencing by Illumina}

At the end of each bioreactor cycle, samples of well-homogenized biomass were collected, centrifuged $\left(10,000 \mathrm{rpm}, 10 \mathrm{~min}\right.$ at $\left.4{ }^{\circ} \mathrm{C}\right)$, washed with PBS and stored at $-20{ }^{\circ} \mathrm{C}$. Total genomic DNA was extracted using a FastDNA SPIN kit for Soil (MP Biomedicals, LLC, Santa Ana, CA) according to manufacturer's instructions.

Amplification, library preparation, sequencing and taxonomic assignment of 16S rRNA reads were done by STAB VIDA (Caparica, Portugal). Library construction was performed using the Illumina $16 \mathrm{~S}$ Metagenomic Sequencing library preparation protocol with the specific bacterial primers set 027F-1492R (Lane, 1991). 16S rRNA genes from the variable V1-V2 regions were sequenced with MiSeq Reagent Kit v3 in 
the Illumina Miseq platform, using 300 bp paired-end sequencing reads.

Bioinformatic analysis were also performed by STAB VIDA (Caparica, Portugal). The analysis of the generated raw sequence was carried out using QIIME2 v2018.11.0 according to Caporaso et al. (2010). The reads were denoised using the DADA2 plugin and the following processes were applied: trimming and truncating low quality regions; dereplicating the reads and filtering chimeras (Callahan et al., 2016). The reads were organized in operational taxonomic units (OTUs) and the taxonomical classification was performed using SILVA database (release 132 QIIME) with a clustering threshold of $97 \%$ similarity. Only OTUs containing at least 10 sequence reads were considered as significant.

Sequencing reads were submitted to the European Nucleotide Archive (ENA) under the study accession number PRJEB37500 (sample SAMEA6791327 - cycle XI A. borkumensis SK2; sample SAMEA6791326 cycle VIII A. borkumensis SK2; sample SAMEA6791328 - cycle VI $R$. opacus B4; sample SAMEA6791329 - cycle II R. opacus B4).

\subsection{Attenuated total reflection-fourier transform infrared analysis (ATR- FTIR)}

Extracts of the intracellular and extracellular lipids resuspended in $0.5 \mathrm{~mL}$ of chloroform were analyzed by ATR-FTIR (attenuated total reflectance-Fourier transform infrared) using a Perkin Elmer Spectrum Two $^{\mathrm{TM}}$ IR spectrometer with a deuterated triglycine sulfate (DTGS) detector and $\mathrm{KBr}$ beam splitter, coupled with an UATR (single reflection diamond, Perkin Elmer) accessory. Samples were applied in the top of the diamond crystal and evaporated to form a film. Complete solvent evaporation was controlled by spectra acquisition until disappearance of the characteristic chloroform band. FTIR spectra were collected at room temperature, in the range of $4000-400 \mathrm{~cm}^{-1}$, with a resolution of 4 $\mathrm{cm}^{-1}$, accumulating 64 scans.

\section{Results and discussion}

\subsection{Evaluation of SBAR performance in the treatment of $L W$ and $P W$ and on the production of lipids}

Microbial growth in both bioreactors ( $\mathrm{SBAR}_{\mathrm{Ab}+\mathrm{PW}}$ and $\left.\mathrm{SBAR}_{\mathrm{R} . \mathrm{o}+\mathrm{LW}}\right)$ was followed by the decrease of $\mathrm{N}^{-\mathrm{NH}_{4}}$ concentration in the culture medium (Fig. 1 (A) and (B)). N-NH $\mathrm{N}_{4}$ consumption in each cycle suggested that bacterial cells in $\mathrm{SBAR}_{\mathrm{Ab}+\mathrm{PW}}$ and $\mathrm{SBAR}_{\mathrm{R} . \mathrm{o}+\mathrm{LW}}$ were able to degrade the hydrocarbons present in the wastewaters and use them as carbon source for growth (Fig. 1 (A) and (B)). $\mathrm{NO}_{2}^{-}$and $\mathrm{NO}_{3}^{-}$concentration in the $\mathrm{SBAR}_{\mathrm{Ab}+\mathrm{PW}}$ effluent was below 2 and $1 \mathrm{mg} \mathrm{L}^{-1}$, respectively. In the case of SBAR $\mathrm{R} . \mathrm{o}+\mathrm{LW} \mathrm{NO}_{2}^{-}$concentration was below $2 \mathrm{mg} \mathrm{L}^{-1}$ and $\mathrm{NO}_{3}^{-}$concentration was approximately $9 \mathrm{mg} \mathrm{L}^{-1}$. The low $\mathrm{NO}_{2}^{-}$and $\mathrm{NO}_{3}^{-}$concentrations observed in both SBAR operations indicates that occurrence of nitrification was not significant. The $\mathrm{N}-\mathrm{NH}_{4}$ profile was a relevant monitoring parameter in the performance of the feast and famine stages, allowing to determine the moment of addition of the wastewater (carbon source).

In the $\mathrm{SBAR}_{\mathrm{Ab}+\mathrm{PW}}$ operation, the microbial growth was similar in all cycles, regardless the nitrogen concentrations used (approximately $0.6 \mathrm{~g} \mathrm{~L}^{-1}$, Table 4), indicating that growth was not influenced by the nitrogen concentration and consequently by the TPH/N ratio. In the case of the $\mathrm{SBAR}_{\text {R.o+LW }}$ operation, accurate biomass quantification was not possible due to the formation of granules by the bacterial biomass.

In the $\mathrm{SBAR}_{\mathrm{Ab}+\mathrm{PW}}$, a TPH removal efficiency up to $96 \% \pm 1.8$ was achieved (Table 4). The preference of $A$. borkumensis SK2 for aliphatic hydrocarbons as sole or main carbon source is well described (Yakimov et al., 1998). Moreover, the ability of A. borkumensis SK2 to remove $\mathrm{n}$-alkanes and other non-polar compounds from PW was already demonstrated by Sudmalis et al. (2018) in batch and continuous stirred tank bioreactor (CSTR). In cycles IV to VIII, a similar TPH removal efficiency was obtained, independently of the feast stage duration. However, when a TPH/N ratio of 9 (cycles I to III and IX to XI) was applied to
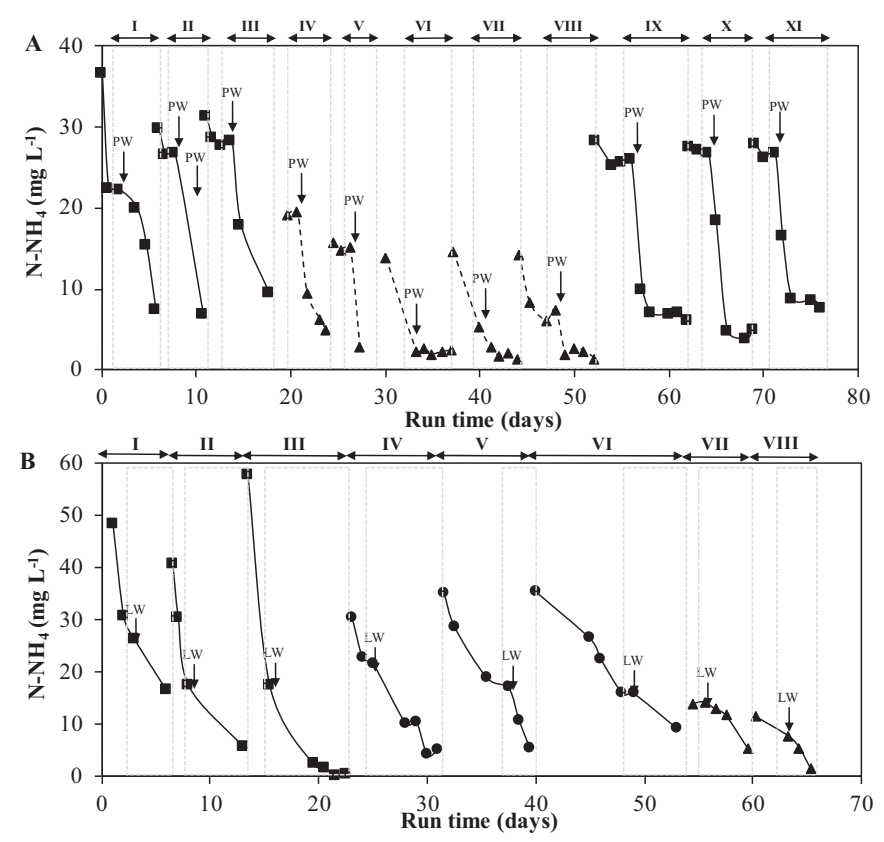

Fig. 1. Ammonium nitrogen $\left(\mathrm{N}-\mathrm{NH}_{4}\right)$ profile during bioreactor operation inoculated with: (A) A. borkumensis SK2 and PW (SBAR $\left.\mathrm{Ab}_{\mathrm{PW}}\right)$ using $0.26 \mathrm{~g} \mathrm{~L}^{-1}$ of TPH and $30 \mathrm{mg} \mathrm{L}^{-1}$ (cycles I-III and IX-XI) and $15 \mathrm{mg} \mathrm{L}^{-1}$ of nitrogen (cycles IV-VIII). (B) $R$. opacus $\mathrm{B} 4$ and $\mathrm{LW}\left(\mathrm{SBAR}_{\mathrm{R} . \mathrm{o}+\mathrm{LW}}\right)$ using $1 \mathrm{~g} \mathrm{~L}^{-1}$ of TPH and $30 \mathrm{mg} \mathrm{L}^{-1}$ of nitrogen (cycles I-III); $4.4 \mathrm{~g} \mathrm{~L}^{-1}$ of TPH and $30 \mathrm{mg} \mathrm{L}^{-1}$ of nitrogen (cycles IV-VI); and $4.4 \mathrm{~g} \mathrm{~L}^{-1}$ of $\mathrm{TPH}$ and $15 \mathrm{mg} \mathrm{L}^{-1}$ of nitrogen (cycles VII-VIII). Gray bars represent the feast stage duration.

the bioreactor ( $0.26 \mathrm{~g} \mathrm{~L}^{-1} \mathrm{TPH}_{\mathrm{PW}}$ and $30 \mathrm{mg} \mathrm{L}^{-1}$ of nitrogen), the increase of the feast stage duration from 2 to 5 days led to an improvement on the TPH removal efficiency of approximately 10\% (Table 4). This result suggests that the feast stage duration applied to the cycles I, II and III (approximately 2 days) was not enough for a complete hydrocarbon removal.

The high salinity levels present in the bioreactor (approximately $30 \mathrm{~g} \mathrm{~L}^{-1}$ ) did not hinder PW treatment, which shows that $A$. borkumensis SK2 was fully adapted to these conditions. Therefore, this bacterium can be considered a robust candidate for the treatment of PW, making the process less time consuming and more cost-effective, since no adaptation period to the high salinity levels was required.

Intracellular and extracellular lipids production was detected for all the TPH/N ratios tested (Table 4). Intracellular lipids content was higher than extracellular, suggesting that accumulation inside the cell was promoted in all of the operational conditions.

Higher intracellular lipid contents were obtained when lower TPH/N ratios and higher feast stages durations were applied to the bioreactor. The highest intracellular lipid production $\left(0.85 \mathrm{~g} \mathrm{~g}^{-1} \mathrm{CDW}\right)$ was achieved in cycle XI when a TPH/N ratio of 10 and a feast stage duration of 5 days were applied. During the $\mathrm{SBAR}_{\mathrm{Ab}+\mathrm{PW}}$ operation the maximum total lipids yield was $1.78 \mathrm{~g}$ of lipids produced per $\mathrm{g}$ of $\mathrm{TPH}_{\mathrm{PW}}$ consumed in cycle XI.

For a TPH/N ratio of approximately $10\left(0.26 \mathrm{~g} \mathrm{~L}^{-1} \mathrm{TPH}_{\mathrm{PW}}\right.$ and $30 \mathrm{mg} \mathrm{L}^{-1}$ of nitrogen), the increase of the feast stage duration from 2 to 5 days (cycles I to III and IX to XI, respectively) led to an increase of approximately 7 times on the intracellular lipids production, increasing from approximately $0.11 \mathrm{~g} \mathrm{~g}^{-1} \mathrm{CDW}$ to $0.74 \mathrm{~g} \mathrm{~g}^{-1} \mathrm{CDW}$. A similar result was observed in cycles IV to VIII $\left(0.26 \mathrm{~g} \mathrm{~L}^{-1} \mathrm{TPH}_{\mathrm{PW}}\right.$ and $15 \mathrm{mg} \mathrm{L}^{-1}$ of nitrogen). With an increase of the feast stage duration from 2 to 4 days, the bacterial cells were able to accumulate approximately $45 \%$ of its cellular dry weight in lipids $\left(0.45 \mathrm{~g} \mathrm{~g}^{-1} \mathrm{CDW}\right)$ (cycles from VI to VIII).

The results indicate that intracellular lipids accumulation in A. borkumensis SK2 was dependent on the TPH/N ratio and on the duration of the feast stage, increasing when higher feast stage duration 
Table 4

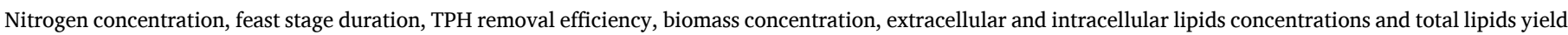
obtained for the different TPH/N ratios applied during the bioreactor operation inoculated with A. borkumensis SK2.

\begin{tabular}{|c|c|c|c|c|c|c|c|c|c|}
\hline \multirow[t]{2}{*}{ Cycles } & \multirow{2}{*}{$\begin{array}{l}\text { Nitrogen } \\
\left(\mathrm{mg} \mathrm{L}^{-1}\right)\end{array}$} & \multirow{2}{*}{$\begin{array}{l}\text { TPH/N } \\
\text { Ratio }^{\mathrm{a}}\end{array}$} & \multirow{2}{*}{$\begin{array}{l}\text { Feast stage } \\
\text { duration }(\mathrm{d})\end{array}$} & \multirow{2}{*}{$\begin{array}{l}\text { Biomass } \\
\left(\mathrm{g} \mathrm{L}^{-1}\right)\end{array}$} & \multirow{2}{*}{$\begin{array}{l}\text { TPH removal } \\
\text { efficiency }(\%)\end{array}$} & \multicolumn{2}{|c|}{ Intracellular lipids } & \multirow{2}{*}{$\begin{array}{l}\text { Extracellular lipids } \\
\left(\mathrm{g} \mathrm{L}^{-1}\right)\end{array}$} & \multirow{2}{*}{$\begin{array}{l}\text { Total lipids yield ( } \mathrm{g} \mathrm{g}^{-1} \\
\text { of TPH } \mathrm{PW}_{\mathrm{P}} \text { consumed) }\end{array}$} \\
\hline & & & & & & $\left(\mathrm{g} \mathrm{L}^{-1}\right)$ & $\begin{array}{l}\left(\mathrm{g} \mathrm{g}^{-1} \text { of }\right. \\
\mathrm{CDW})\end{array}$ & & \\
\hline I & 30 & 13 & 2 & 0.95 & $85 \pm 2.5$ & 0.15 & 0.20 & 0.12 & 1.19 \\
\hline II & 30 & 10 & 2 & 0.56 & $90 \pm 3.5$ & 0.06 & 0.12 & 0.02 & 0.36 \\
\hline III & 30 & 9 & 3 & 0.63 & $85 \pm 1.6$ & 0 & 0 & 0.02 & 0.10 \\
\hline IV & 15 & 13 & 2 & 0.69 & $94 \pm 3.7$ & 0 & 0 & 0.01 & 0.02 \\
\hline $\mathbf{V}$ & 15 & 17 & 1 & 0.61 & $90 \pm 8.6$ & 0.003 & 0.02 & 0.01 & 0.05 \\
\hline VI & 15 & 107 & 4 & 0.69 & $95 \pm 0.5$ & 0.22 & 0.40 & 0.05 & 1.08 \\
\hline VII & 15 & 49 & 4 & 0.57 & $95 \pm 1.3$ & 0.17 & 0.53 & 0.07 & 0.94 \\
\hline VIII & 15 & 35 & 4 & 0.56 & $94 \pm 2.1$ & 0.11 & 0.42 & 0.05 & 0.63 \\
\hline IX & 30 & 10 & 6 & 0.65 & $93 \pm 0.5$ & 0.25 & 0.64 & 0.03 & 1.14 \\
\hline $\mathbf{X}$ & 30 & 10 & 5 & 0.60 & $95 \pm 0.1$ & 0.16 & 0.74 & 0.06 & 0.88 \\
\hline XI & 30 & 10 & 5 & 0.60 & $96 \pm 1.8$ & 0.28 & 0.85 & 0.18 & 1.78 \\
\hline
\end{tabular}

${ }^{\text {a }}$ Correspond to the TPH/N ratio applied to the bioreactor at the start of the feast stage. This ratio was calculated by dividing the TPH concentration added to the bioreactor at the start of the feast stage by the nitrogen concentration inside of the bioreactor at that moment.

and lower TPH/N ratio were applied. Although the production of storage compounds is usually associated with unbalanced growth conditions (excess of carbon and limited amount of an essential nutrient, such as nitrogen), the results suggest that accumulation of neutral lipids in A. borkumensis SK2 from PW is not fully related with nitrogen limitation. Indeed, higher intracellular lipids accumulation was achieved for higher nitrogen concentrations ( $30 \mathrm{mg} \mathrm{L}^{-1}$ of nitrogen). Therefore, it seems that nitrogen availability in the environment was the most relevant factor to promote intracellular lipids production during $\mathrm{SBAR}_{\mathrm{Ab}+\mathrm{PW}}$ operation.

Extracellular lipids production seems not to be directly influenced by nitrogen availability or feast stage duration, since similar concentrations (approximately $0.06 \mathrm{~g} \mathrm{~L}^{-1}$ ) were obtained in all the conditions tested. Extracellular lipids production metabolism in A. borkumensis SK2 is not yet well understood, however it is suggested that neutral lipid excretion may be related to biosurfactants production (Manilla-Pérez et al., 2010b). A. borkumensis is known to produce a glycolipid biosurfactant in the presence of n-alkanes in order to access and metabolize easily hydrophobic substrates (Perfumo et al., 2010; Yakimov et al., 1998). Production of extracellular lipids by $A$. borkumensis SK2 is an advantage for the valorization of PW treatment, since production of neutral lipids is not limited by the cell volume, and therefore can make the process more economically viable.

Intracellular lipids accumulation from real PW by A. borkumensis SK2 was already demonstrated by Sudmalis et al. (2018) during a CSTR operation. The authors reported a similar intracellular lipid accumulation as the obtained in this work (approximately $0.31 \mathrm{~g} \mathrm{~L}^{-1}$ ) for a carbon concentration of $0.20 \mathrm{~g} \mathrm{~L}^{-1}$, a similar value as the TPH concentration added to the SBAR $\left(0.26 \mathrm{~g} \mathrm{~L}^{-1}\right.$ of TPH). Accumulation of intracellular lipids by $A$. borkumensis SK2 from simple substrates such as pyruvate and hexadecane was also reported (Kalscheuer et al., 2007). The maximum lipid content produced from these simple carbon sources was approximately $23 \%$ (from pyruvate) and $9 \%$ (from hexadecane) in CDW. The results obtained in this work showed that from a real oilfield produced water and with a SBAR system $A$. borkumensis SK2 could reach up to $80 \%$ of its CDW.

Concerning the treatment of LW in the SBAR inoculated with R. opacus B4, the TPH removal efficiency varied between $55 \%$ and $79 \%$ (Table 5). The highest TPH removal efficiency (79\%) was achieved in cycle III, which corresponded to the operational conditions of $1 \mathrm{~g} \mathrm{~L}^{-1}$ of TPH and $30 \mathrm{mg} \mathrm{L}^{-1}$ of nitrogen (Table 5). The increase of the TPH concentration from 1 to $4.4 \mathrm{~g} \mathrm{~L}^{-1}$ did not influence $\mathrm{LW}$ treatment, since similar TPH removal efficiencies were obtained throughout the process. Therefore, the results suggested that the microbial community was only capable to partially degrade the hydrocarbons present in LW. Lubricant oil is composed by a complex mixture of hydrocarbons and an unresolved complex matrix (Da Silva et al., 2016; Frysinger et al., 2003). This fraction, was reported as the most resistant to biodegradation (Frysinger et al., 2003), and may be the fraction not degraded in both TPH concentrations tested which explains the similar TPH removal efficiencies observed.

During $\mathrm{SBAR}_{\text {R.o+LW }}$ operation, higher neutral lipid concentrations were achieved when higher $\mathrm{TPH} / \mathrm{N}$ ratios were applied (cycles III to VIII) (Table 5). The highest intracellular lipids production attained was $0.94 \mathrm{~g} \mathrm{~g}^{-1} \mathrm{CDW}$ in cycle VI, for a TPH/N ratio of 476 . The results showed that the carbon concentration was the most important factor for lipids accumulation in $R$. opacus B4. Indeed, the increase of the TPH concentration from $1 \mathrm{~g} \mathrm{~L}^{-1}$ to $4.4 \mathrm{~g} \mathrm{~L}^{-1}$ led to a correspondent increase in the lipid accumulation (approximately 4.4 times higher).

Intracellular lipid content in $\mathrm{SBAR}_{\mathrm{R} . \mathrm{o}+\mathrm{LW}}$ operation was not significantly affected by the feast stage duration. The highest lipid production rate (of $0.34 \mathrm{~g} \mathrm{~L}^{-1} \mathrm{~d}^{-1}$ ) and lipid yield (of $0.13 \mathrm{~g} \mathrm{~g}^{-1} \mathrm{PW}$ consumed)

Table 5

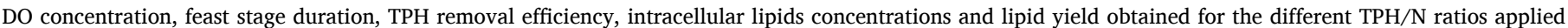
during the bioreactor operation inoculated with $R$. opacus $\mathrm{B} 4$.

\begin{tabular}{|c|c|c|c|c|c|c|c|c|}
\hline Cycle & $\begin{array}{l}\text { Nitrogen } \\
\left(\mathrm{mg} \mathrm{L}^{-1}\right)\end{array}$ & $\begin{array}{l}\mathbf{T P H}_{\mathrm{LW}} \\
\left(\mathrm{g} \mathrm{L}^{-1}\right)\end{array}$ & $\begin{array}{l}\text { TPH/N } \\
\text { Ratio }^{\text {a }}\end{array}$ & $\begin{array}{l}\text { Feast stage } \\
\text { duration (d) }\end{array}$ & $\begin{array}{l}\text { TPH removal } \\
\text { efficiency (\%) }\end{array}$ & $\begin{array}{l}\text { Intracellular lipids } \\
\left.\text { ( } \mathrm{g} \mathrm{g}^{-1} \text { of } \mathrm{CDW}\right)\end{array}$ & $\begin{array}{l}\text { Lipids production } \\
\text { rate }\left(\mathrm{g} \mathrm{L}^{-1} \mathrm{~d}^{-1}\right)\end{array}$ & $\begin{array}{l}\text { Lipids Yield ( } \mathrm{g} \mathrm{g}^{-1} \\
\mathrm{TPH}_{\mathrm{LW}} \text { consumed) }\end{array}$ \\
\hline I & 30 & 1 & 61 & 4 & $56 \pm 1.17$ & 0.13 & 0.03 & 0.02 \\
\hline II & 30 & 1 & 175 & 5 & $46 \pm 0$ & 0.18 & 0.02 & 0.02 \\
\hline III & 30 & 1 & 3247 & 7 & $79 \pm 1.49$ & 0.28 & 0.03 & 0.02 \\
\hline IV & 30 & 4.4 & 861 & 2 & n.d & 0.84 & 0.06 & n.d \\
\hline V & 30 & 4.4 & 809 & 2 & n.d & 0.84 & 0.23 & n.d \\
\hline VI & 30 & 4.4 & 476 & 4 & $71 \pm 0.6$ & 0.94 & 0.03 & 0.04 \\
\hline VII & 15 & 4.4 & 815 & 2 & $55 \pm 2.1$ & 0.92 & 0.05 & 0.04 \\
\hline VIII & 15 & 4.4 & 2821 & 1 & $57 \pm 3.8$ & 0.87 & 0.34 & 0.13 \\
\hline
\end{tabular}

${ }^{\text {a }}$ Correspond to the real TPH/N ratio applied to the bioreactor at the start of the feast stage. This ratio was calculated by dividing the TPH concentration added to the bioreactor at the start of the feast stage by the nitrogen concentration inside of the bioreactor at that moment. 
were obtained in the operational conditions of $4.4 \mathrm{~g} \mathrm{~L}^{-1} \mathrm{TPH}_{\mathrm{LW}}$ and $15 \mathrm{mg} \mathrm{L}^{-1}$ of nitrogen and shorter feast stage duration (1 day in cycle VIII). A similar outcome was observed for the operational condition of $4.4 \mathrm{~g} \mathrm{~L}^{-1} \mathrm{TPH}_{\mathrm{LW}}$ and $30 \mathrm{mg} \mathrm{L}^{-1}$ of nitrogen. A high lipid production rate of $0.23 \mathrm{~g} \mathrm{~L}^{-1} \mathrm{~d}^{-1}$ was achieved once again in the cycle with the lower feast stage duration ( 2 days in cycle $\mathrm{V}$ ).

The $\mathrm{SBAR}_{\mathrm{R} . \mathrm{o}+\mathrm{LW}}$ results showed that $\mathrm{TPH} / \mathrm{N}$ ratio was the most relevant parameter in neutral lipid accumulation, which is in accordance with the results reported by Castro et al. (2018).

The obtained results showed the suitability of the SBAR design for the aerobic biological treatment of different types of mineral oil-based wastewaters and its valorization for the production of neutral lipids. SBAR systems are commonly used for the removal of nutrients and/or toxic compounds from several wastewaters, including saline wastewaters (Li et al., 2017; Nguyen et al., 2016). From the authors knowledge, this is the first time that the feasibility of a SBAR system for an efficient aerobic biological treatment of different types of mineral oil-wastewaters coupled with neutral lipids production is reported.

\subsection{Neutral lipids identification by ATR-FTIR}

The lipid extracts obtained from both reactors were analyzed by ATRFTIR, in order to identify the different types of lipids produced during the biological treatment of PW and LW. Several studies have reported the feasibility of this technique for the determination of the lipid content accumulated in oleaginous yeasts and microalgae in response to nutrient stress conditions such as nitrogen limitation (Esther Elizabeth Grace et al., 2020). The absorption bands observed in the wavenumber range from 4000 to $500 \mathrm{~cm}^{-1}$ were assigned to specific molecular groups based on published studies (Table 6). As reported in the literature, absorption bands in the spectral regions of $3020-2800 \mathrm{~cm}^{-1}, 1800-1700 \mathrm{~cm}^{-1}$, $1500-1300 \mathrm{~cm}^{-1}, 1100-1200 \mathrm{~cm}^{-1}$ and $800-700 \mathrm{~cm}^{-1}$ are related to lipidic groups (Table 6) (Shapaval et al., 2019).

Only the spectrums that corresponded to the operational conditions with higher lipids production in $\mathrm{SBAR}_{\mathrm{Ab}+\mathrm{PW}}$ and $\mathrm{SBAR}_{\mathrm{R} . \mathrm{o}+\mathrm{LW}}$ were analyzed by ATR-FTIR.

Fig. 2 shows the FTIR spectrum correspondent to the intracellular and extracellular lipids produced by the bacterial cells, likely of A. borkumensis SK2, in cycle $\mathrm{XI}$ of $\mathrm{SBAR}_{\mathrm{Ab}+\mathrm{PW}}$ operation (Fig. 2(A)) and the intracellular lipids produced by the bacterial cells, likely of $R$. opacus

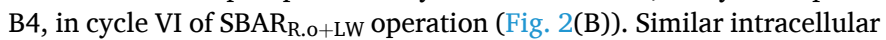
and extracellular lipids spectrum profiles were obtained throughout $\mathrm{SBAR}_{\mathrm{Ab}+\mathrm{PW}}$ and $\mathrm{SBAR}_{\mathrm{R} . \mathrm{O}+\mathrm{LW}}$ operation, showing that the same type of lipids were accumulated, regardless of the operational conditions applied during the treatment process. However, significant differences in the absorption frequencies were observed between the intracellular and extracellular lipids spectrums of $\mathrm{SBAR}_{\mathrm{Ab}+\mathrm{PW}}$ (Fig. 2(A)), suggesting the production of different types of lipids intra- and extracellularly.

The intracellular lipids spectra for both SBAR operation $\left(\mathrm{SBAR}_{\mathrm{Ab}+\mathrm{PW}}\right.$

Table 6

Assignment of the bands found in ATR-FTIR spectrum of extracellular and intracellular lipids extracts of $\mathrm{SBAR}_{\mathrm{Ab}+\mathrm{PW}}$ and $\mathrm{SBAR}_{\mathrm{R} . \mathrm{o}+\mathrm{LW}}$ operations according to literature.

\begin{tabular}{|c|c|}
\hline $\begin{array}{l}\text { Wavenumber range } \\
\left(\mathrm{cm}^{-1}\right)\end{array}$ & Band assignment from the literature \\
\hline 2955 & stretching vibration of acyl chains $\nu_{\mathrm{as}}\left(\mathrm{CH}_{3}\right)$ \\
\hline 2920 & $\begin{array}{l}\text { stretching vibration of asymmetric acyl chains } \\
\nu_{\mathrm{as}}\left(\mathrm{CH}_{2}\right)\end{array}$ \\
\hline 2850 & stretching vibration of symmetric acyl chains $\nu_{\mathrm{s}}\left(\mathrm{CH}_{2}\right)$ \\
\hline 1708 & $\begin{array}{l}\text { stretching vibration of the ester group } \nu\left(C^{=}=0\right) \text { in fatty } \\
\text { acids }\end{array}$ \\
\hline 1740 & stretching vibration of the ester group $\nu\left(\mathrm{C}^{=} \mathrm{O}\right)$ in TAGs \\
\hline 1460 & asymmetric bending vibration of acyl chains $\delta_{\text {as }}\left(\mathrm{CH}_{3}\right)$ \\
\hline 1370 & symmetric bending vibration of acyl chains $\delta_{\mathrm{s}}\left(\mathrm{CH}_{3}\right)$ \\
\hline 1300-1100 & stretching vibration of esters $\nu$ (C-O) \\
\hline 720 & methylene rocking vibration $\rho\left(\mathrm{CH}_{2}\right)$ \\
\hline
\end{tabular}

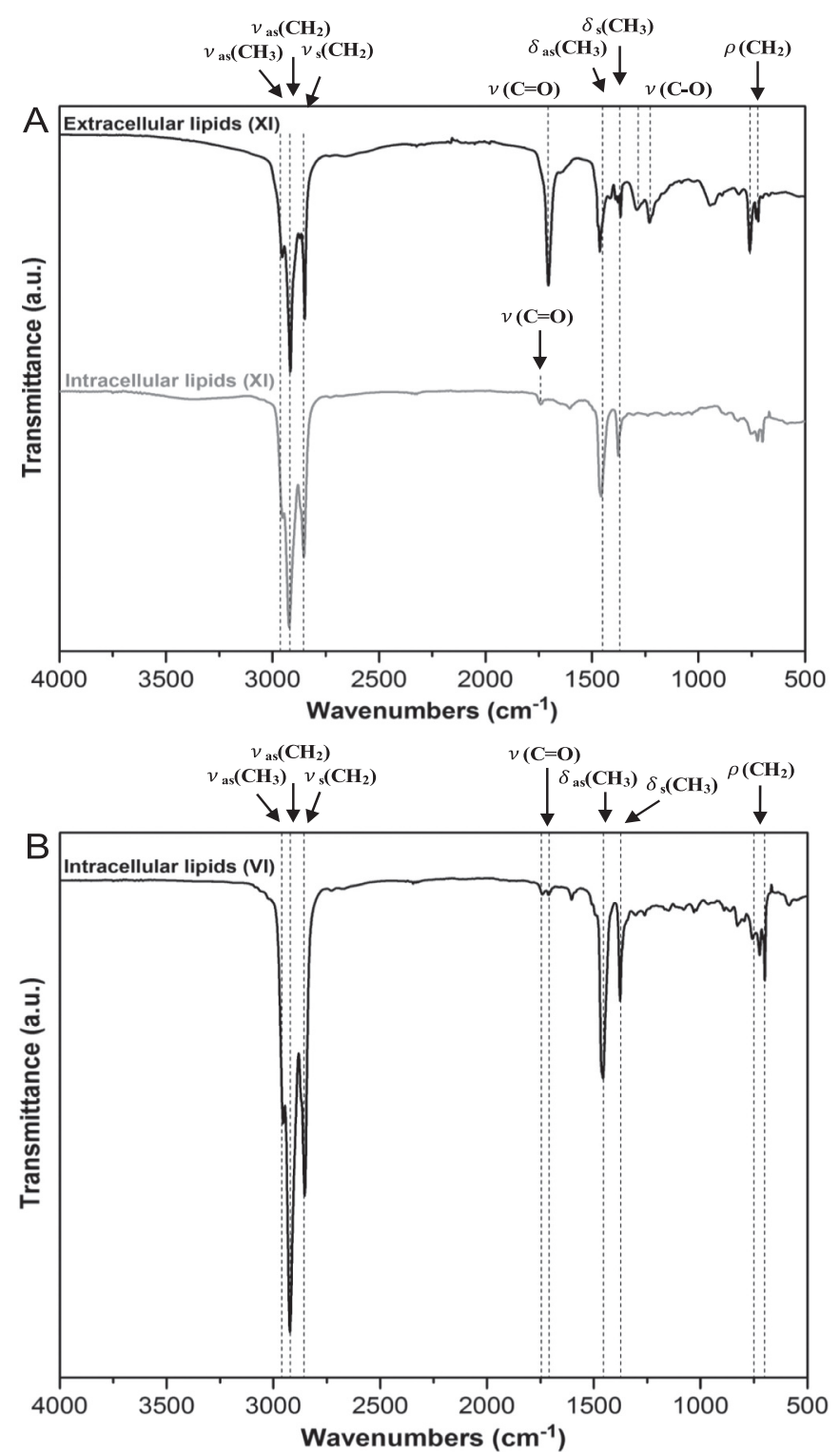

Fig. 2. ATR-FTIR spectrum of the lipids produced by: (A) A. borkumensis SK2 and (B) $R$. opacus $\mathrm{B} 4$ during $\mathrm{SBAR}_{\mathrm{Ab}+\mathrm{PW}}$ and $\mathrm{SBAR}_{\mathrm{R} . \mathrm{o}+\mathrm{LW}}$ operations, respectively.

and $\left.\mathrm{SBAR}_{\mathrm{R} . \mathrm{O}+\mathrm{LW}}\right)$ revealed characteristic absorption bands around $2955 \mathrm{~cm}^{-1}, 2925 \mathrm{~cm}^{-1}$ and $2850 \mathrm{~cm}^{-1}$, assigned to asymmetric $\nu_{\text {as }}\left(\mathrm{CH}_{3}\right)$, asymmetric $\nu_{\text {as }}\left(\mathrm{CH}_{2}\right)$ and symmetric $\nu_{\mathrm{s}}\left(\mathrm{CH}_{2}\right)$ stretching vibrations of acyl chains from fatty acids present in TAGs, respectively (Shapaval et al., 2019); and a band at $1745 \mathrm{~cm}^{-1}$, attributed to the stretching vibration of the ester group $\nu\left(C^{=} \mathrm{O}\right)$ in the carbonyl group of TAG (Fig. 2) (Esther Elizabeth Grace et al., 2020). This peak is a characteristic vibration representative of the presence of TAG (Esther Elizabeth Grace et al., 2020), suggesting that this type of neutral lipids was the most predominant type accumulated intracellularly by both microorganisms.

In the intracellular lipid spectrum of $\mathrm{SBAR}_{\mathrm{R} . \mathrm{o}+\mathrm{LW}}$ and in the extracellular lipid spectrum of $\mathrm{SBAR}_{\mathrm{Ab}+\mathrm{PW}}$ a band at $1710 \mathrm{~cm}^{-1}$ corresponding to the stretching in esters $\nu\left(C^{=}=\right)$was detected which can indicate the presence of free fatty acids (Shapaval et al., 2019).

The extracellular lipid spectrum profile of $\mathrm{SBAR}_{\mathrm{Ab}+\mathrm{PW}}$ showed characteristic absorption bands at approximately $2955 \mathrm{~cm}^{-1} \nu_{\text {as }}\left(\mathrm{CH}_{3}\right)$, $2925 \mathrm{~cm}^{-1} \nu_{\text {as }}\left(\mathrm{CH}_{2}\right)$ and $2850 \mathrm{~cm}^{-1} \nu_{\mathrm{s}}\left(\mathrm{CH}_{2}\right)$; additional peaks in the region between 1300 and $1100 \mathrm{~cm}^{-1}$ which are related to the stretching 
vibration of esters $\nu(\mathrm{C}-\mathrm{O})$, as well as the presence of a band at $1700 \mathrm{~cm}^{-1}$, typical of the absorption frequency for the carbonyl group in aliphatic esters $\nu\left(C^{=}=0\right)$. This result suggests the extracellular production of WE by A. borkumensis SK2 (Dubis et al., 1999; Forfang et al., 2017).

Other absorption bands characteristic of lipids were detected in the extracellular and intracellular spectrums of $\mathrm{SBAR}_{\mathrm{Ab}+\mathrm{PW}}$ and $\mathrm{SBAR}_{\mathrm{R}}$. $o+\mathrm{LW}$. An absorption band at approximately $720 \mathrm{~cm}^{-1}$ that corresponds to the methylene rocking vibration $\rho\left(\mathrm{CH}_{2}\right)$, and two bands near $1460 \mathrm{~cm}^{-1}$ and $1380 \mathrm{~cm}^{-1}$, corresponding to the asymmetric $\delta_{\text {as }}\left(\mathrm{CH}_{3}\right)$ and symmetric $\delta_{\mathrm{s}}\left(\mathrm{CH}_{3}\right)$ bending vibration of acyl chains, respectively (Forfang et al., 2017).

The ATR-FTIR spectra were in accordance with the neutral lipid analysis using TLC (Fig. S3 and S4). Bands correspondent to TAG and FA were detected in the intracellular lipids fraction of $S_{B A R} A b+P W$, indicating that TAG was the dominant neutral lipid accumulated. Bands correspondent to WE were not observed (Fig. S3 (A)). On the other hand, in the extracellular lipid profile a band correspondent to WE was detected in cycles VI, VII, IX and XI, confirming the ATR-FTIR results (Fig. S3 (B) and Table 4). Bands with very low intensity correspondent to TAG production were detected but only in cycles VI and IX (Fig. S3 (B)). In cycle VIII, the presence of the band correspondent to WE was not detected, which explains the absence of the absorption bands in the range of $1300-1100 \mathrm{~cm}^{-1}$ related to $\nu$ (C-O) (data not shown).

TLC neutral lipid profile from SBAR $_{\mathrm{R} . \mathrm{o}+\mathrm{LW}}$ also confirmed the presence of TAG and FA in the intracellular lipid extract from cycle VI (Fig. S4). Moreover, the TLC analysis showed that TAG and FA were produced in all cycles, with more intense bands in the cycles IV, $\mathrm{V}$ and VI, which corresponded to the operational conditions with higher lipid accumulation (4.4 $\mathrm{g} \mathrm{L}^{-1}$ of LW and $30 \mathrm{mg} \mathrm{L}^{-1}$ of nitrogen) (Fig. S4 and Table 5).

During PW treatment, A. borkumensis SK2 was able to produce WE and TAG. However, WE was detected in the extracellular fraction while TAG where predominantly detected in the intracellular content, which is in accordance with Sudmalis et al. (2018). The ability of Alcanivorax genus to produce neutral lipids such as TAG and WE, both intra- and extracellularly, from hexadecane, under unbalanced growth conditions, is reported in literature (Manilla-Pérez et al., 2011, 2010a). The genes atfA1 and atfA2 that encode for a homologous wax ester synthase/ acyl coenzyme A (acyl-CoA): diacylglycerol acyltransferase (WS/DGAT) were detected in the genome of $A$. borkumensis SK2, which is responsible for the synthesis of WE and TAG (Kalscheuer et al., 2007).

TAG production by A. borkumensis SK2 was reported to be related to nitrogen limiting conditions while WE-like compounds were growthlinked (nitrogen limiting-independent) when cultivated in a bioreactor under controlled batch conditions (Da Silva et al., 2016). This explains the higher neutral lipids productions obtained in the present study when higher nitrogen concentrations were applied to the bioreactor.

During $\mathrm{SBAR}_{\mathrm{R} . \mathrm{o}+\mathrm{LW}}$ operation, $R$. opacus $\mathrm{B} 4$ was able to accumulate intracellular TAG, however WE production was not observed (Fig. S3). TLC of the intracellular lipids of both $\mathrm{SBAR}_{\mathrm{Ab}+\mathrm{PW}}$ and $\mathrm{SBAR}_{\mathrm{R} . \mathrm{o}+\mathrm{LW}}$, showed additional bands correspondent to TAG precursors, such as acylglycerols (MAG), diacylglycerols (DAG) and fatty acids (FA) (Fig. S3 and S4).

The results obtained in this study indicate that bacterial neutral lipid profiles and its production depends on the characteristics of the mineral oil-wastewater used as carbon source (i.e hydrocarbons profile and the salinity levels), and the cellular machinery of the bacterial species present in the bacterial community.

\subsection{Bacterial community developed during $P W$ and $L W$ treatment}

Since both $\mathrm{SBAR}_{\mathrm{Ab}+\mathrm{PW}}$ and $\mathrm{SBAR}_{\mathrm{R} . \mathrm{o}+\mathrm{LW}}$ were operated under nonsterile conditions and LW and PW may have its own microbial community, it is likely that $A$. borkumensis SK2 and $R$. opacus B4 were not the only microorganisms inside the bioreactor. In $\mathrm{SBAR}_{\mathrm{Ab}+\mathrm{PW}}, 16 \mathrm{~S}$ rRNA gene sequencing analysis of samples collected at cycle VIII $\left(15 \mathrm{mg} \mathrm{L}^{-1}\right.$ of nitrogen) and XI ( $30 \mathrm{mg} \mathrm{L}^{-1}$ of nitrogen) showed that Alcanivorax sp. was the most dominant microorganism within the bioreactor throughout the operation process. Alcanivorax sp. relative abundance represented approximately $80 \%$ and $76 \%$ of the total bacterial community in cycle VIII and XI, respectively (Fig. 3). As described by Sudmalis et al. (2018) and Kasai et al. (2002), Alcanivorax sp. metabolism is fully adapted to $\mathrm{n}$-alkanes degradation and is known that Alcanivorax genus becomes dominant in the microbial community of petroleum-contaminated seawaters when nitrogen and phosphorus are supplied in adequate amounts (Kasai et al., 2002). Under these conditions, Alcanivorax sp. relative abundance can reach approximately $80-90 \%$ of the total oil-degrading microbial community (Martins dos Santos et al., 2010). Therefore, it is expected that Alcanivorax sp. remains the most dominant microorganism within the bioreactor.

Achromobacter genus was also detected in the bacterial community with a relative abundance of $5 \%$ and $9 \%$ in cycles VIII and XI, respectively (Fig. 3). Members of Achromobacter genus were described as capable of aliphatic and aromatic hydrocarbons degradation and also as biosurfactant producers (Gielnik et al., 2019; Joy et al., 2017). Moreover, in the presence of crude oil some Achromobacter sp. produced a glycolipid with biosurfactant activity (Joy et al., 2017). Nevertheless, the high abundance of $A$. borkumensis SK2 in the microbial community during bioreactor operation suggests that this bacterium is a key player during PW treatment in SBAR.

Regarding the $\mathrm{SBAR}_{\mathrm{R} . \mathrm{o}+\mathrm{LW}}$, the $16 \mathrm{~S}$ rRNA gene sequencing analysis showed that Pseudomonas sp. and Rhodococcus sp. were the most dominant microorganisms with a relative abundance of $42.8 \%$ and $20.6 \%$ in cycle II and $8.3 \%$ and $9.6 \%$ in cycle VI, respectively (Fig. 4). Pseudomonas sp. have been reported as able to degrade aromatic and/or aliphatic hydrocarbons and also to be the most dominant microorganism in environments with high concentrations of n-alkanes and cycloalkanes (Muriel-Millán et al., 2019). Pseudomonas sp. is known to mainly accumulate polyhydroxyalkanoates as reserve materials of carbon and energy (Mozejko-Ciesielska et al., 2019).

Several aerobic bacterial genera reported in literature capable of hydrocarbons degradation were detected in the microbial community develop throughout the reactor operation (Fig. 4). The most represented genera, with relative abundances higher than $5 \%$ were Ochrobactrum, Sphingobacterium and Novosphingobium. These bacterial genera have preferentially degraded aromatic hydrocarbons, particularly polycyclic

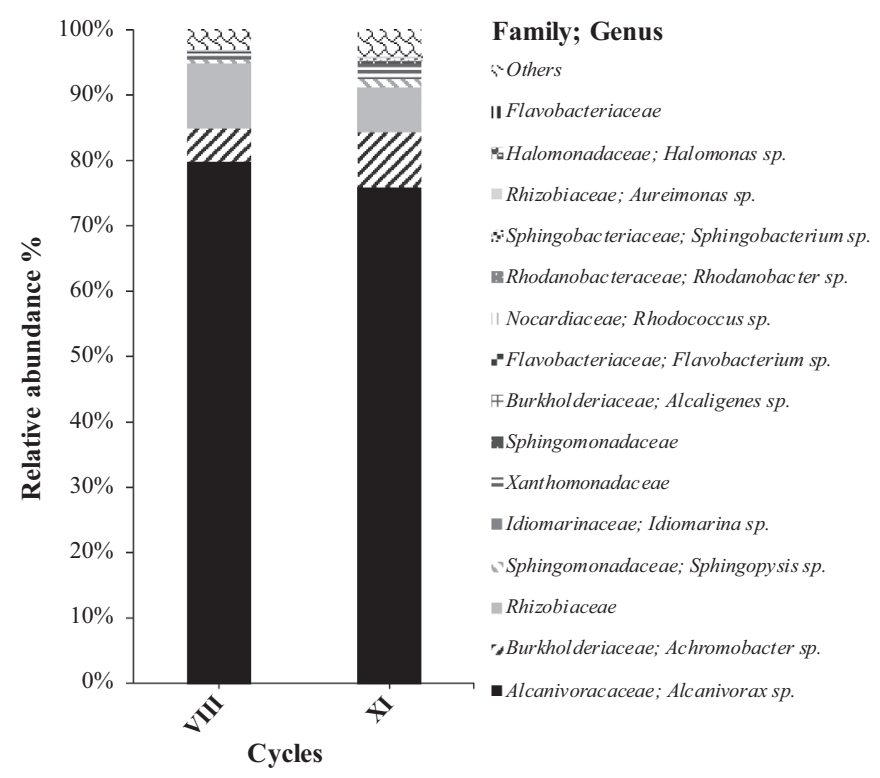

Fig. 3. Bacterial community composition during bioreactor operation with A. borkumensis SK2 treating $\mathrm{PW}\left(\mathrm{SBAR}_{\mathrm{Ab}+\mathrm{PW}}\right)$. Only bacterial families and genera with relative abundance above $1 \%$ are represented. 


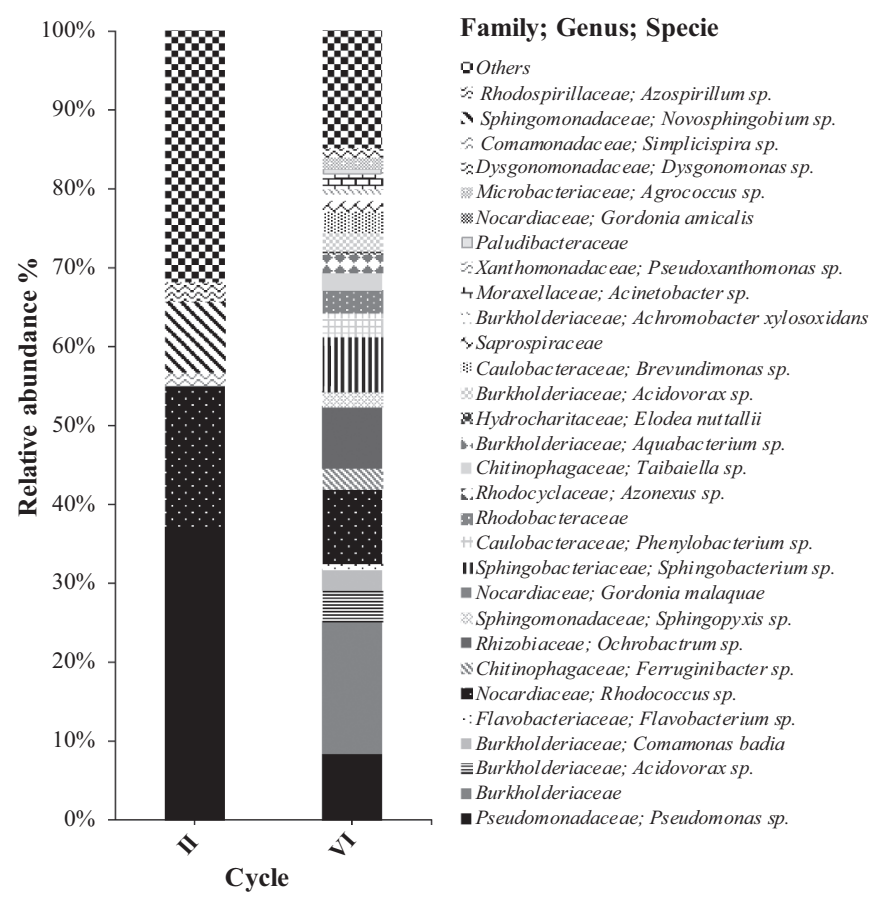

Fig. 4. Bacterial community composition during bioreactor inoculated with R. opacus $\mathrm{B} 4$ treating $\mathrm{LW}\left(\mathrm{SBAR}_{\mathrm{R} . \mathrm{o}+\mathrm{LW}}\right)$. Only bacterial families and genera with relative abundance above $1 \%$ were represented.

aromatic hydrocarbons (PAHs) that are commonly used for the manufacture of lubricating oils (Abou-shanab, 2015; Kertesz and Kawasaki, 2010; Satti et al., 2019). The lubricant wastewater used as carbon source in this study can explain the development of a bacterial community specialized in the biodegradation of these hydrocarbons. Due to n-alkanes low solubility and reactivity, and the complexity of PAHs, the biodegradation of these compounds represents a challenge to bacteria. Therefore, the development of bacterial communities in this work, able to degrade these compounds is an advantage for the treatment of both mineral oil-wastewaters used (PW and LW).

Although the microbial community analysis showed the presence of several bacterial genera able to degrade hydrocarbons, the ability for neutral lipids accumulation was only assigned to the Alcanivorax and Rhodococcus genera.

\section{Conclusion}

This work demonstrated the feasibility of a SBAR for the treatment of PW and LW and its valorization for neutral lipids production by $A$. borkumensis SK2 and $R$. opacus $\mathrm{B} 4$, respectively.

The results obtained suggest that a specialized inoculum needs to be used according to the mineral oil-wastewater characteristics. Moreover, the results demonstrated that the neutral lipid profile and its production is influenced by the inoculum and the operational conditions applied to the SBAR. Particularly, the nitrogen concentration is a determinant parameter for neutral lipids production by $A$. borkumensis SK2 from saline hydrocarbon wastewaters. For non-saline wastewaters, R. opacus B4 is a suitable candidate and the carbon source concentration is the most important factor for neutral lipids accumulation. TAGs were the main neutral lipids accumulated by $R$. opacus B4. In A. borkumensis SK2, WE production was mostly extracellular whilst TAG production was intracellular. This is an interesting result, since the different types of neutral lipids can be used for different industrial applications, in order to make the biological treatment of mineral oil-wastewaters more sustainable. In sum, this work shows that different operation strategies need to be applied depending on the type of mineral oil-wastewater and highlights the relevance of the bacterial lipid location (intracellular or extracellular) in defining the most suitable operational strategy to maximize neutral lipids production.

\section{CRediT authorship contribution statement}

All authors contributed intellectually via scientific discussions during the work and have been involved in drafting the manuscript and revising it critically. Silva RM helped to design the experiments, performed the experimental work, analysed and interpreted the data and wrote the manuscript. Fernandes AM and Fiume $\mathrm{F}$ performed the experimental work related to LW treatment. Castro AR helped with TPH and lipids analyses. Machado R helped with ATR-FTIR analysis and data interpretation. Pereira MA designed the experiments, supervised all the experimental work, contributed to data interpretation and reviewed the manuscript.

\section{Declaration of Competing Interest}

The authors declare that they have no known competing financial interests or personal relationships that could have appeared to influence the work reported in this paper.

\section{Acknowledgments}

This work was supported by the Portuguese Foundation for Science and Technology (FCT) and European Regional Development Fund (FEDER) under the scope of project SaltOil+ (POCI-01-0145-FEDER030180); the strategic programmes UIDB/04469/2020, UID/BIA/4050/ 2013 (POCI-01-0145-FEDER-007569) and UID/BIA/04050/2019; and by the BioTecNorte operation (NORTE-01-0145-FEDER-000004) funded by the European Regional Development Fund under the scope of Norte2020 - Programa Operacional Regional do Norte. Research of Rita M. Silva was supported by PhD grant SFRH/BD/116154/2016, funded by FCT.

\section{Appendix A. Supporting information}

Supplementary data associated with this article can be found in the online version at doi:10.1016/j.jhazmat.2020.124492.

\section{References}

Abou-shanab, R., 2015. Petroleum hydrocarbon degradation potential of Ochrobactrum lupini Isolated from BTEX enrichment soil. Int. J. Environ. 204-209. ISSN 2077-4508 4.

Aljuboury, Dr.D., Palaniandy, P., Aziz, H.A., Feroz, H., 2017. Treatment of petroleum wastewater by conventional and new technologies A review. Glob. Nest J.

Alvarez, H., Steinbüchel, A., 2002. Triacylglycerols in prokaryotic microorganisms. Appl. Microbiol. Biotechnol. 60, 367-376. https://doi.org/10.1007/s00253-002-1135-0.

Callahan, B.J., McMurdie, P.J., Rosen, M.J., Han, A.W., Johnson, A.J.A., Holmes, S.P., 2016. DADA2: high-resolution sample inference from Illumina amplicon data. Nat. Methods 13, 581-583. https://doi.org/10.1038/nmeth.3869.

Camarillo, M.K., Stringfellow, W.T., 2018. Biological treatment of oil and gas produced water: a review and meta-analysis. Clean Technol. Environ. Policy 20, 1127-1146. https://doi.org/10.1007/s10098-018-1564-9.

Caporaso, J.G., Kuczynski, J., Stombaugh, J., Bittinger, K., Bushman, F.D., Costello, E.K., Fierer, N., Peña, A.G., Goodrich, J.K., Gordon, J.I., Huttley, G.A., Kelley, S.T., Knights, D., Koenig, J.E., Ley, R.E., Lozupone, C.A., McDonald, D., Muegge, B.D., Pirrung, M., Reeder, J., Sevinsky, J.R., Turnbaugh, P.J., Walters, W.A., Widmann, J., Yatsunenko, T., Zaneveld, J., Knight, R., 2010. QIIME allows analysis of highthroughput community sequencing data. Nat. Methods 7, 335-336. https://doi.org/ 10.1038/nmeth.f.303.

Castro, A.R., Guimarães, M., Oliveira, J.V., Pereira, M.A., 2017. Production of added value bacterial lipids through valorisation of hydrocarbon-contaminated cork waste. Sci. Total Environ. 605-606, 677-682. https://doi.org/10.1016/j. scitotenv.2017.06.216.

Castro, A.R., Rocha, I., Alves, M.M., Pereira, M.A., 2016. Rhodococcus opacus B4: a promising bacterium for production of biofuels and bio-based chemicals. AMB Express 6. https://doi.org/10.1186/s13568-016-0207-y.

Castro, A.R., Silva, P.T.S., Castro, P.J.G., Alves, E., Domingues, M.R.M., Pereira, M.A., 2018. Tuning culturing conditions towards the production of neutral lipids from 
lubricant-based wastewater in open mixed bacterial communities. Water Res. 144, 532-542. https://doi.org/10.1016/j.watres.2018.07.068.

Dong, Z., Lu, M., Huang, W., Xu, X., 2011. Treatment of oilfield wastewater in moving bed biofilm reactors using a novel suspended ceramic biocarrier. J. Hazard. Mater. 196, 123-130. https://doi.org/10.1016/j.jhazmat.2011.09.001.

Dubis, E.N., Dubis, A.T., Morzycki, J.W., 1999. Comparative analysis of plant cuticular waxes using HATR FT-IR reflection technique. J. Mol. Struct. 511-512, 173-179. https://doi.org/10.1016/S0022-2860(99)00157-X.

Esther Elizabeth Grace, C., Lakshmi, P. Kiruthika, Meenakshi, S., Vaidyanathan, S., Srisudha, S., Mary, M. Briget, 2020. Biomolecular transitions and lipid accumulation in green microalgae monitored by FTIR and Raman analysis. Spectrochim. Acta Part A Mol. Biomol. Spectrosc. 224, 117382 https://doi.org/10.1016/j.saa.2019.117382.

Fakhru'l-Razi, A., Pendashteh, A., Abdullah, L.C., Biak, D.R.A., Madaeni, S.S., Abidin, Z. Z., 2009. Review of technologies for oil and gas produced water treatment. J. Hazard. Mater. 170, 530-551. https://doi.org/10.1016/j.jhazmat.2009.05.044.

Forfang, K., Zimmermann, B., Kosa, G., Kohler, A., Shapaval, V., 2017. FTIR spectroscopy for evaluation and monitoring of lipid extraction efficiency for Oleaginous fungi. PLoS One 12, e0170611. https://doi.org/10.1371/journal.pone.0170611.

Frysinger, G.S., Gaines, R.B., Xu, L., Reddy, C.M., 2003. Resolving the unresolved complex mixture in petroleum-contaminated sediments. Environ. Sci. Technol. 37, 1653-1662. https://doi.org/10.1021/es020742n.

Gielnik, A., Pechaud, Y., Huguenot, D., Cébron, A., Esposito, G., van Hullebusch, E.D., 2019. Bacterial seeding potential of digestate in bioremediation of diesel contaminated soil. Int. Biodeterior. Biodegrad. 143, 104715 https://doi.org/ 10.1016/j.ibiod.2019.06.003.

Heider, J., Spormann, A.M., Beller, H.R., Widdel, F., 1998. Anaerobic bacterial metabolism of hydrocarbons. FEMS Microbiol. Rev. 22, 459-473. https://doi.org/ 10.1111/j.1574-6976.1998.tb00381.x.

Jiménez, S., Micó, M.M., Arnaldos, M., Medina, F., Contreras, S., 2018. State of the art of produced water treatment. Chemosphere 192, 186-208. https://doi.org/10.1016/j. chemosphere.2017.10.139.

Joy, S., Rahman, P.K.S.M., Sharma, S., 2017. Biosurfactant production and concomitant hydrocarbon degradation potentials of bacteria isolated from extreme and hydrocarbon contaminated environments. Chem. Eng. J. 317, 232-241. https://doi. org/10.1016/j.cej.2017.02.054.

Kalscheuer, R., Stoveken, T., Malkus, U., Reichelt, R., Golyshin, P.N., Sabirova, J.S., Ferrer, M., Timmis, K.N., Steinbüchel, A., 2007. Analysis of storage lipid accumulation in Alcanivorax borkumensis: evidence for alternative triacylglycerol biosynthesis routes in bacteria. J. Bacteriol. 189, 918-928. https://doi.org/10.1128/ JB.01292-06.

Kasai, Y., Kishira, H., Sasaki, T., Syutsubo, K., Watanabe, K., Harayama, S., 2002. Predominant growth of Alcanivorax strains in oil-contaminated and nutrientsupplemented sea water. Environ. Microbiol. 4, 141-147. https://doi.org/10.1046/ j.1462-2920.2002.00275.x.

Kertesz, M.A., Kawasaki, A., 2010. Hydrocarbon-degrading sphingomonads: Sphingomonas, Sphingobium, Novosphingobium, and Sphingopyxis. In: Timmis, K.N. (Ed.), Handbook of Hydrocarbon and Lipid Microbiology. Springer, Berlin Heidelberg, Berlin, Heidelberg, pp. 1693-1705. https://doi.org/10.1007/978-3540-77587-4_119.

Kumar, S., Gupta, N., Pakshirajan, K., 2015. Simultaneous lipid production and dairy wastewater treatment using Rhodococcus opacus in a batch bioreactor for potential biodiesel application. J. Environ. Chem. Eng. 3, 1630-1636. https://doi.org/ 10.1016/j.jece.2015.05.030.

Lane, D.J., 1991. 16S/23S rRNA Sequencing. In: Stackebrandt, E., Goodfellow, M. (Eds.), Nucleic Acid Techniques in Bacterial Systematic. John Wiley and Sons, New York, pp. 115-175.

Li, X., Luo, J., Guo, G., Mackey, H.R., Hao, T., Chen, G., 2017. Seawater-based wastewater accelerates development of aerobic granular sludge: a laboratory proofof-concept. Water Res. 115, 210-219. https://doi.org/10.1016/j. watres.2017.03.002.

Manilla-Pérez, E., Lange, A.B., Hetzler, S., Steinbüchel, A., 2010a. Occurrence, production, and export of lipophilic compounds by hydrocarbonoclastic marine bacteria and their potential use to produce bulk chemicals from hydrocarbons. Appl. Microbiol. Biotechnol. 86, 1693-1706. https://doi.org/10.1007/s00253-010-25155.

Manilla-Pérez, E., Lange, A.B., Hetzler, S., Wältermann, M., Kalscheuer, R., Steinbüchel, A., 2010b. Isolation and characterization of a mutant of the marine bacterium Alcanivorax borkumensis SK2 defective in lipid biosynthesis. Appl. Environ. Microbiol. 76, 2884-2894. https://doi.org/10.1128/AEM.02832-09.

Manilla-Pérez, E., Lange, A.B., Luftmann, H., Robenek, H., Steinbüchel, A., 2011. Neutral lipid production in Alcanivorax borkumensis SK2 and other marine hydrocarbonoclastic bacteria. Eur. J. Lipid Sci. Technol. 113, 8-17. https://doi.org/ 10.1002/ejlt.201000374.

Martins dos Santos, V., Sabirova, J., Timmis, K.N., Yakimov, M.M., Golyshin, P.N., 2010. Alcanivorax borkumensis. In: Timmis, Kenneth N. (Ed.), Handbook of Hydrocarbon and Lipid Microbiology. Springer, Berlin Heidelberg, Berlin, Heidelberg, pp. 1265-1288. https://doi.org/10.1007/978-3-540-77587-4_89.

Mozejko-Ciesielska, J., Szacherska, K., Marciniak, P., 2019. Pseudomonas species as producers of eco-friendly polyhydroxyalkanoates. J. Polym. Environ. 27, 1151-1166. https://doi.org/10.1007/s10924-019-01422-1.

Muriel-Millán, L.F., Rodríguez-Mejía, J.L., Godoy-Lozano, E.E., Rivera-Gómez, N., Gutierrez-Rios, R.-M., Morales-Guzmán, D., Trejo-Hernández, M.R., EstradasRomero, A., Pardo-López, L., 2019. Functional and genomic characterization of a Pseudomonas aeruginosa strain isolated from the Southwestern Gulf of Mexico reveals an enhanced adaptation for long-chain alkane degradation. Front. Mar. Sci. 6, 572. https://doi.org/10.3389/fmars.2019.00572.

Nguyen, Phuong, Nguyen, Phuoc, Truong, H., Bui, H., 2016. The formation and stabilization of aerobic granular sludge in a sequencing batch airlift reactor for treating Tapioca-processing wastewater. Pol. J. Environ. Stud. 25, 2077-2084. https://doi.org/10.15244/pjoes/62736.

Perfumo, A., Smyth, T.J.P., Marchant, R., Banat, I.M., 2010. Production and roles of biosurfactants and bioemulsifiers in accessing hydrophobic substrates. In: Timmis, K. N. (Ed.), Handbook of Hydrocarbon and Lipid Microbiology. Springer, Berlin Heidelberg, Berlin, Heidelberg, pp. 1501-1512. https://doi.org/10.1007/978-3540-77587-4_103.

Revellame, E.D., Hernandez, R., French, W., Holmes, W.E., Benson, T.J., Pham, P.J., Forks, A., Callahan II, R., 2012. Lipid storage compounds in raw activated sludge microorganisms for biofuels and oleochemicals production. RSC Adv. 2. https://doi. org/10.1039/c2ra01078j.

Satti, S.M., Shah, A.A., Auras, R., Marsh, T.L., 2019. Genome annotation of Poly(lactic acid) degrading Pseudomonas aeruginosa and Sphingobacterium sp. Microbiology. https://doi.org/10.1101/609883.

Schlegel, H.G., Kaltwasser, H., Gottschalk, G., 1961. Ein Submersverfahren zur Kultur wasserstoffoxydierender Bakterien: Wachstumsphysiologische Untersuchungen. Arch. Mikrobiol. 38, 209-222. https://doi.org/10.1007/BF00422356.

Shapaval, V., Brandenburg, J., Blomqvist, J., Tafintseva, V., Passoth, V., Sandgren, M., Kohler, A., 2019. Biochemical profiling, prediction of total lipid content and fatty acid profile in oleaginous yeasts by FTIR spectroscopy. Biotechnol. Biofuels 12, 140 . https://doi.org/10.1186/s13068-019-1481-0.

Da Silva, P.D.M.P., Lima, F., Alves, M.M., Bijmans, M.F.M., Pereira, M.A., 2016 Valorization of lubricant-based wastewater for bacterial neutral lipids production: growth-linked biosynthesis. Water Res. 101, 17-24. https://doi.org/10.1016/j. watres.2016.05.062.

Sudmalis, D., Da Silva, P., Temmink, H., Bijmans, M.M., Pereira, M.A., 2018. Biological treatment of produced water coupled with recovery of neutral lipids. Water Res. 147, 33-42. https://doi.org/10.1016/j.watres.2018.09.050.

Yakimov, M.M., Golyshin, P.N., Lang, S., Moore, E.R.B., Abraham, W.-R., Lünsdorf, H., Timmis, K.N., 1998. Alcanivorax borkumensis gen. nov., sp. nov., a new, hydrocarbon-degrading and surfactant-producing marine bacterium. Int. J. Syst. Bacteriol. 48, 339-348. https://doi.org/10.1099/00207713-48-2-339.

Zhang, X., Chen, J., Wu, D., Li, J., Tyagi, R.D., Surampalli, R.Y., 2019. Economical lipid production from Trichosporon oleaginosus via dissolved oxygen adjustment and crude glycerol addition. Bioresour. Technol. 273, 288-296. https://doi.org/10.1016/j. biortech.2018.11.033. 